\title{
Immobilisation of catalase on the surface of biodegradable starch-based polymers as a way to change its surface characteristics
}

\author{
S. A. $\operatorname{COSTA}^{1,2 *}$, R. L. REIS ${ }^{1,2}$ \\ ${ }^{1} 3 B^{\prime}$ 's Research Group, Biomaterials, Biodegradables and Biomimetics, Campus de Gualtar, \\ 4710-057 Braga, Portugal \\ ${ }^{2}$ Department of Polymer Engineering, University of Minho, Campus de Azurém, 4800-058 \\ Guimarães, Portugal \\ E-mail: silgia@dep.uminho.pt
}

In this study, a specific enzyme catalase was immobilised onto the surface of two different biodegradable materials, starch cellulose acetate (SCA) and starch polycrapolactone (SPCL) blends. This immobilisation was achieved by several different routes, mainly by covalent binding and an adsorption method using as activation agents epichlorohydrin, cyanogen bromide ( $\mathrm{CNBr}$ ), and aminopropyltriethoxysilane. The effect of the coupling $\mathrm{pH}$ of the enzyme-support reaction was determined in terms of activity recovery (\%). The catalase immobilised on SCA showed higher activity recovery (\%) for all the methods used as compared with results obtained with SPCL. The immobilisation process using epichlorohydrin as an activation agent and polyethylenimine as a spacer-arm enhanced the stability and the half-lives at $\mathrm{pH} 7.0,30^{\circ} \mathrm{C}$, for immobilised catalase on both SCA and SPCL. The half-lives were respectively, 1162 and $870 \mathrm{~h}$ compared with other treatments and free enzyme $(480 \mathrm{~h})$. The free glycerol present in the immobilisation medium was also a factor that contributed toward the better performance regarding the long-term stability at $30^{\circ} \mathrm{C}$ and neutral $\mathrm{pH}$. The extension of the morphological modifications on the surface of the materials was observed by scanning electron microscopy. In general, the results indicated that the chemical modification with epichlorohydrin could provide a simple and rather efficient technique to modify the starch-based materials' surface that might be useful in several biomedical applications.

(C) 2004 Kluwer Academic Publishers

\section{Introduction}

In recent years, many biodegradable polymers have been proposed to be used in tissue engineering to build a threedimensional (3-D) porous structure to provide scaffolds for cells toward the regeneration of tissue-engineered organs such as liver, bone cartilage, and artificial skin [15]. It is has been found to be difficult to transplant cells in to some biodegradable scaffolds as in many cases cell attachment on these materials is rather limited $[6,7]$. Many methods like plasma-treatment-induced graft polymerisation, ozone oxidation, and immobilisation of enzymes or special biologically active compounds have been assessed in order to try to introduce useful reactive groups onto polymeric surfaces [8-10].

There are several methods of immobilising proteins and enzymes on a substrate for biomedical and biochemical applications [11]. These can be divided into two general categories: physical and chemical $[12,13]$. Five major protein immobilisation techniques are currently being used. These are: (a) entrapment, which is physical trapping of the active components into a film, gel, fibre, coating, or microencapsulation [14, 15]; (b) covalent binding, in which attachment of the active component to the substrate is through a chemical reaction or linkage to activated surface groups [16,17]; (c) ionic binding, which is based, mainly, on ionic binding of the enzyme or an active molecule to solid supports containing ion-exchange residues [18, 19]; (d) physical adsorption, which applies a protein to a substrate or film and allows the molecule to adsorb to the substrate over a specified time period [20,21]; and (e) crosslinking, a method based on the formation of covalent bonds between the enzyme or active molecules, by means of bi- or multifunctional reagents [22,23].

In relation to the use of immobilised enzymes with therapeutic use, catalase is one of the most interesting ones because it is employed to accelerate healing as well as to correct hereditary deficiencies [24,25] and, in

*Author to whom all correspondence should be addressed. 
combination with hydrogen peroxide, as an antiseptic against anaerobes $[26,27]$. The catalase enzyme has the ability to decompose hydrogen peroxide into oxygen and water, playing a central role in controlling the concentration of hydrogen peroxide in human cells $[28,29]$. More than $98 \%$ of blood catalase is localised in erythrocytes. These cells, with their high catalase content provide a general protection against the toxic concentration of this small hydrogen peroxide molecule. The deficiency of catalase could be causes of diseases such as acatalasemia [30,31]. Several methods have been developed for the preparation of immobilised catalase, each having its own advantages and disadvantages [3235].

Enzyme immobilisation is often accompanied by changes in enzymatic activity, optimum $\mathrm{pH}$, affinity to the substrate, stability, etc. The extent of these changes depends on the enzyme and carrier support, and on the immobilisation conditions [36]. Starch cellulose acetate (SCA) and starch polycrapolactone (SPCL) blends are biocompatible thermoplastics with properties that are useful for several biomedical applications [37-40]. Hence, these materials are regarded as a suitable matrix for the immobilisation of enzymes and active molecules [41].

In the present study, SCA and SPCL were activated via a chemical modification. Catalase was then covalently immobilised on the materials surface via the reacting groups $\left(\mathrm{NH}_{2}\right.$ and aldehydes) using three different agents of activation (epichlorohydrin, cyanogen bromide $(\mathrm{CNBr})$, and aminopropyltriethoxysilane (ATPS)). The physical adsorption method was also used for catalase immobilisation and the respective results have been compared. The aim of the study was to see the effect of chemical and physical modifications of the starch-based polymers on the stability and half-life of catalase after immobilisation. Enzyme-modifying materials are then aimed to be used for tissue engineering scaffolding applications.

\section{Materials and methods}

\subsection{Materials}

The materials used were blends of corn starch with cellulose acetate $50 / 50 \mathrm{wt} \%$ (SCA) and polycrapolactone $30 / 70 \mathrm{wt} \%$ (SPCL). The polymers were obtained from Novamont, Italy, and were processed by injection molding (discs $\varnothing 3.3 \mathrm{~mm}$ ). Chemicals, including hydrogen peroxide, epichlorohydrin, polyethylenimine, glutaraldehyde, CNBr, $\gamma$-ATPS, sodium hydroxide, were purchased from Sigma Chemical Co. (St Louis, MO). Terminox Ultra (EC 1.11.1.6) is a catalase enzyme produced by the submerged fermentation of a Scytalidium microorganism and was obtained from Aquitex, Portugal.

\subsection{Catalase immobilisation methods}

\subsubsection{Epichlorohydrin treatment}

SCA and SPCL discs $(\sim 3.0 \mathrm{~g})$ were activated by immersion in $2 \%(\mathrm{v} / \mathrm{v})$ epichlorohydrin/ $\mathrm{NaOH} 1 \mathrm{~N}$ solution at $50{ }^{\circ} \mathrm{C}$ for $10 \mathrm{~min}$. The discs were thoroughly washed with distilled water and immersed in $2 \%(\mathrm{v} / \mathrm{v})$ aqueous polyethylenimine solution for $2 \mathrm{~h}$ at room temperature. The washed materials were immersed in $0.5 \%(\mathrm{v} / \mathrm{v})$ of glutaraldeyde solution for $2 \mathrm{~h}$ at room temperature. After $2 \mathrm{~h}$ of incubation, the materials were removed and washed with distilled water and dried at $40^{\circ} \mathrm{C}$ for $2 \mathrm{~h}$. Then, the discs were immersed in $20 \mathrm{ml}$ of the enzyme solution ( $358 \mathrm{U} / \mathrm{g}$ support and $19 \mathrm{mg}$ protein/g support) by way of diluting 10 times the original enzyme solution with a universal buffer $(\mathrm{pH} 3-$ 12) for $19 \mathrm{~h}$ at room temperature. After the desired contact time, the residual enzyme was filtered and the support was washed with the same buffer. The activity and percentage of catalase immobilised was determined as described in Section 2.2.5.

\subsubsection{Cyanogen bromide treatment}

SCA and SPCL discs $(\sim 3.0 \mathrm{~g})$ were activated by immersion in $10 \%(\mathrm{w} / \mathrm{v}) \mathrm{CNBr}(\mathrm{pH} 11.0)$ solution for $24 \mathrm{~h}$, at room temperature. After $24 \mathrm{~h}$ the samples were rinsed with distilled water and $0.1 \mathrm{M}$ sodium carbonate buffer in order for to remove free CNBr. The materials were dried at $40{ }^{\circ} \mathrm{C}$ for $2 \mathrm{~h}$ and then incubated in $20 \mathrm{ml}$ of enzyme solution $(358 \mathrm{U} / \mathrm{g}$ support and $19 \mathrm{mg}$ protein/g support 1) obtained by diluting 10 times the original enzyme solution with universal buffer $(\mathrm{pH} 3-12)$ for $19 \mathrm{~h}$ at room temperature. After this period, SCA and SPCL disks with immobilised catalase were removed from the enzyme solution and washed with same buffer three times. The activity and percentage of catalase immobilised were determined as described in Section 2.2.5.

\subsubsection{Aminopropyltriethoxysilane treatment}

SCA and SPCL discs $(\sim 3.0 \mathrm{~g})$ were silanised by immersion in $2.5 \%(\mathrm{v} / \mathrm{v}) \gamma$-ATPS in water solution at $50{ }^{\circ} \mathrm{C}$ for $24 \mathrm{~h}$. The silanised supports were thoroughly washed with distilled water immersed in $2 \%(\mathrm{v} / \mathrm{v})$ aqueous glutaraldeyde solution for $2 \mathrm{~h}$ at room temperature. After $2 \mathrm{~h}$ they were washed again with distilled water and dried at $40^{\circ} \mathrm{C}$ for $2 \mathrm{~h}$. Afterwards, SCA and SPCL supports were immersed in $20 \mathrm{ml}$ of enzyme solution (358 U/g support and $19 \mathrm{mg}$ protein/g support) obtained by diluting 10 times the original enzyme solution with universal buffer $(\mathrm{pH} \mathrm{3-12)}$ for $19 \mathrm{~h}$ at room temperature. After this period, SCA and SPCL discs with immobilised catalase were removed from the enzyme solution and washed with same buffer three times. The activity and percentage of catalase immobilised were determined as described in Section 2.2.5.

\subsubsection{Adsorption}

The SCA and SPCL discs $(\sim 3.0 \mathrm{~g})$ were immersed into a flask containing $20 \mathrm{ml}$ catalase solution $(358 \mathrm{U} / \mathrm{g}$ support and $19 \mathrm{mg}$ protein/g support) obtained by diluting 10 times the original enzyme solution with universal buffer ( $\mathrm{pH} 3-12$ ) for $19 \mathrm{~h}$ at room temperature. After this period, SCA and SPCL discs with immobilised catalase were removed from the enzyme solution and washed with same buffer three times. The activity and 
percentage of catalase immobilised were determined as described in Section 2.2.5.

\subsubsection{Activity assays of free and immobilised catalase}

Free and immobilised catalase activity was determined spectrophotometrically at $240 \mathrm{~nm}$ (UV-1601 Shimadzu Recording Spectrophotometer), following the degradation of $26 \mathrm{mM} \mathrm{H}_{2} \mathrm{O}_{2}$ in buffer phosphate $(\mathrm{pH} \mathrm{7.0)}$ at $30{ }^{\circ} \mathrm{C}[32,42]$. Activity recovery $(\mathrm{AR} \%)$ was defined as

$$
\mathrm{AR} \%=U_{0} / U_{\mathrm{ads}} \times 100
$$

where $U_{0}$ is the activity present in the immobilisation solution, and $U_{\text {ads }}$ the difference between the initial activity $\left(U_{0}\right)$ of the native enzyme added and that remaining in the supernatant at the end of the immobilisation procedure.

\subsection{The thermal stability of free and immobilised catalase}

The thermal stability of free and immobilised catalase was evaluated at $37 \pm 1{ }^{\circ} \mathrm{C}$ in $50 \mathrm{mM}$ phosphate buffer, pH $7.4 \pm 0.02$. These experimental conditions were selected to mimic the human body. After incubation for different time periods, the remaining activity was measured in the dehydration of hydrogen peroxide as described above in Section 2.2.5.

\subsection{Scanning electron microscopy}

The morphology of the surface of SCA and SPCL samples before and after treatments as examined by scanning electron microscopy (SEM). Samples were sputter-coated with gold and scanned at $10 \mathrm{kV}$ by SEM (Leica Cambridge S-360) equipped with a LINK eXLII $\mathrm{X}$-ray energy dispersion spectrometer used for microanalysis of the possible presence of iron in the samples.

\section{Results and discussion}

\subsection{Effect of immobilisation $\mathrm{pH}$ on activity of catalase}

A variety of supports and techniques has been used for the immobilisation of enzymes, cells, and active molecules $[43,44]$. The amount of protein or enzyme bound to a support will also directly depend on the coupling reaction conditions used, for example, available linking group, time, temperature, $\mathrm{pH}$, and concentration of the enzyme. The ionisation state of the active site of the enzyme molecule must be affected by the type, the concentration, and the $\mathrm{pH}$ of the buffer salts used in the immobilisation process. The influence of the catalase $\mathrm{pH}$ solution during the immobilisation process, using different agents for the activation of SCA and SPCL ( $\gamma$ ATPS, epichlorohydrin, $\mathrm{CNBr}$, adsorption), is shown in Figs. 1-4. In fact, it was observed that the activity recovery $(\%)$ was very sensitive to the $\mathrm{pH}$ of the catalase solution during the binding step of the immobilisation process for all the methods. In the first case, SCA and SPCL supports were activated with $\gamma$-ATPS without

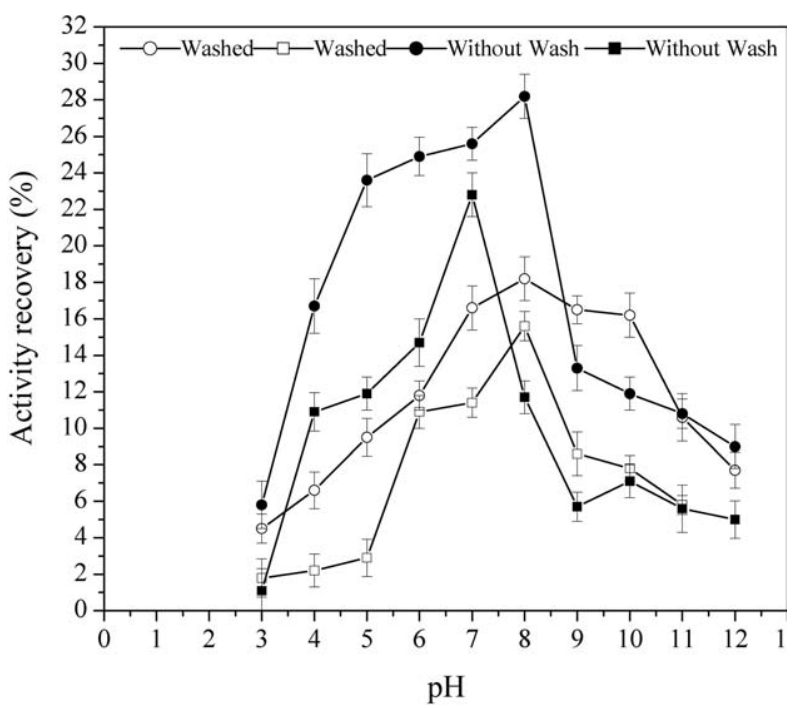

Figure 1 Effect of the $\mathrm{pH}$ of the immobilisation solution on catalase activity recovery (\%) on SCA and SPCL. SCA and SPCL were activated with ATPS before (- - SCA, - $\square$ - SPCL) and after (-O- SCA, - $\square$ SPCL) washing of the materials.

being previously washed of the material or after five days of washing in distilled water for the removal of glycerol (used as plasticiser during processing) (Fig. 1). The maximum activity recovery (\%) was found to be $28.2 \%$ at $\mathrm{pH} 8.0$ and $22.8 \%$ at $\mathrm{pH} 7.0$ for SCA and SPCL without washing and $18.2 \%$ and $15.6 \%$ at $\mathrm{pH} 7.0$, respectively, for both washed materials. This effect could probably be due to the presence of free glycerol in the immobilisation solution. The increase in enzyme $\mathrm{pH}$ and thermal stability due to the presence of glycerol used as a plasticiser when preparing the starch-based thermoplastics could partly be explained by the preservation of the protein hydration at the surface of the enzyme (Fig. 1(a)). The denaturation of the enzyme in aqueous solution proceeds generally via the exposure of hydrophobic parts of the protein in water, which give rise to unfolding, and is certainly accompanied by a loss of a number of essential water molecules, leading to irreversible inactivation due to wrong structural rearrangements. The polyol molecules (e.g. glycerol, polyethylene glycol, ficoll) may be preferentially excluded from the surface layer of the protein molecule and the water shell around the enzyme is preserved; that is, the conformation of the protein becomes more rigid. In the medium with three components (water, protein, polyol), interactions occurring between the polyol and the protein, leading to the displacement of the same water molecules surrounding the protein molecule, will be a function of protein affinity for the additive [45-47]. Castro Guillermo [48] reported that $\alpha$-chymotrypsin showed higher stability at alkaline $\mathrm{pH}$ in the presence of glycerol. Due to the effect of stabilisation presented by the glycerol during the immobilisation procedure (using as activation agent $\gamma$ ATPS) in this study, we decided not to wash the materials for the other immobilisation processes that are discussed below.

The covalently bonded catalase in SCA and SPCL had a maximum activity recovery (\%) of $30.4 \%$ and $28.1 \%$ and an optimum $\mathrm{pH} 10.0$ for both materials when epichlorohydrin was used as the activation agent and 


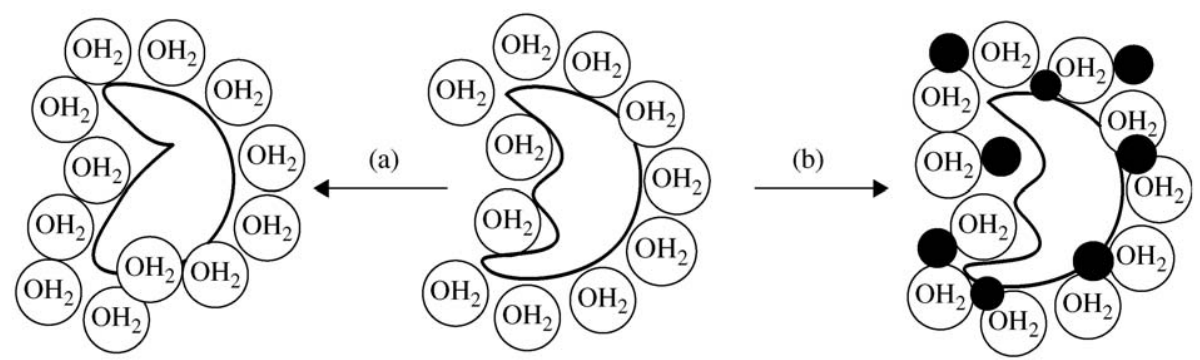

Figure 1(a) Denaturation of the enzyme in aqueous medium (a) and the effect of glycerol on the stabilisation of the enzyme (b).

polyethylenimine (PEI) as a spacer-arm (Fig. 2). PEI is non-toxic and the US FDA has permitted the use of PEI in food as a secondary direct food additive under the Federal Food, Drug and Cosmetic Act [49]. SPCL exhibited a sigmoidal bell shaped curve ( $\mathrm{pH}$ 6-11) compared to SCA, which can be an advantage in future applications. The increase in immobilisation $\mathrm{pH}$ may arise from changing the conformational integrity of the enzyme structure by covalent bond formation via amino groups. The covalent bond formation might also reduce the conformational flexibility of the enzyme molecule and may impart higher activation energy for the molecule to reorganise to the appropriate conformation for catalysis to occur [15]. In this case, the used spacer molecule gives a greater degree of mobility to the coupled biocatalyst so that its activity can, under certain circumstances, be higher than when it is bound directly to the carrier.

The ability of the immobilised catalase to remain active was also tested using $\mathrm{CNBr}$ as the activation agent. The activity recovery (\%) after catalase immobilisation in SCA and SPCL, using CNBr as activation agent, was, respectively, $36.0 \%$ and $20.6 \%$ (Fig. 3). As can be also seen in Fig. 3, the optimum $\mathrm{pH}$ value shifted 1 unit to the alkaline region after immobilisation of catalase via $\mathrm{CNBr}$ coupling for the SPCL samples as compared to the SCA samples. The higher value of activity recovery (\%) obtained for SCA could be perhaps explained by the presence of more hydroxyl groups on the SCA surface that tends to offer attachment sites for enzymes via

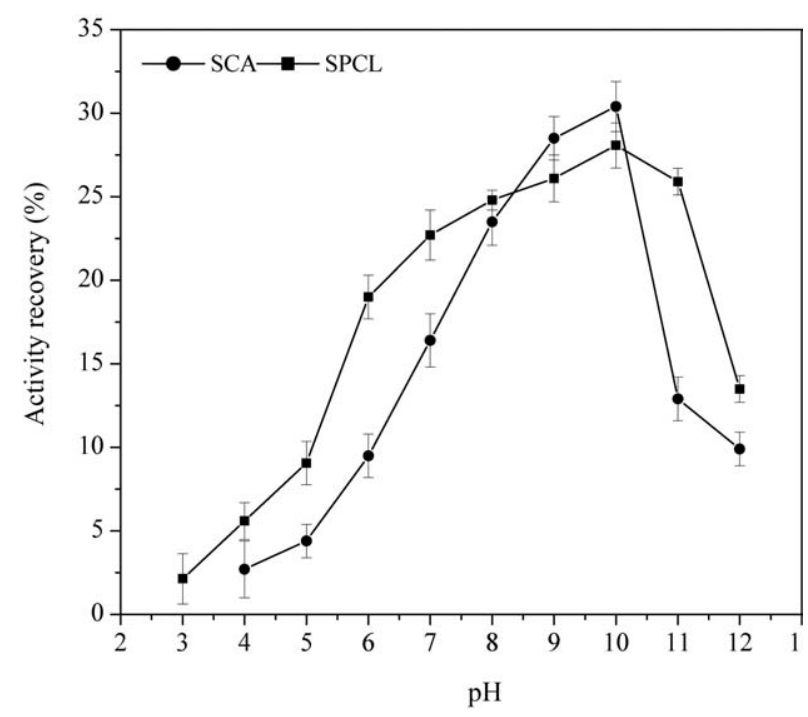

Figure 2 Effect of the $\mathrm{pH}$ of the immobilisation solution on catalase activity recovery (\%) on (--) SCA and (- -) SPCL. SCA and SPCL were activated with epichlorohydrin. activation. Natural polymers (e.g. cellulose, dextran, starch, or agarose) that contain a large number of hydroxyl groups can be easily activated with $\mathrm{CNBr}$ [50]. In fact, hydroxyl groups have been used in the previous enzyme immobilisation studies either by entrapment, into, and by covalent binding and absorption onto membranes and microspheres [20,49]. However, the use of $\mathrm{CNBr}$ presents one main disadvantage: it is volatile and extremely toxic, deteriorating easily during its storage.

Adsorption is the immobilisation method by which an enzyme is attached to a surface through non-covalent interactions. It is a technique with high commercial potential because adsorption is simpler and less expensive and high catalytic activity may be retained as compared to other methods. The method also offers the reusability of expensive supports after the immobilisation of the enzyme. However, adsorption is generally not very strong and some of the absorbed proteins will desorb during washing and other requires operational steps. Thus, immobilisation via absorption requires an electrostatic interaction between the enzyme and the support [33]. The catalase immobilised in SCA and SPCL by the adsorption method exhibited an activity recovery $(\%)$ of $18.65 \%$ and $16.6 \%$, respectively (Fig. 4). The optimal $\mathrm{pH}$ values for the immobilisation procedure in SCA and SPCL was found, in this case, to be 9.0 and 10.0, respectively. For all the treatments SCA presented higher activity recovery when compared to SPCL.

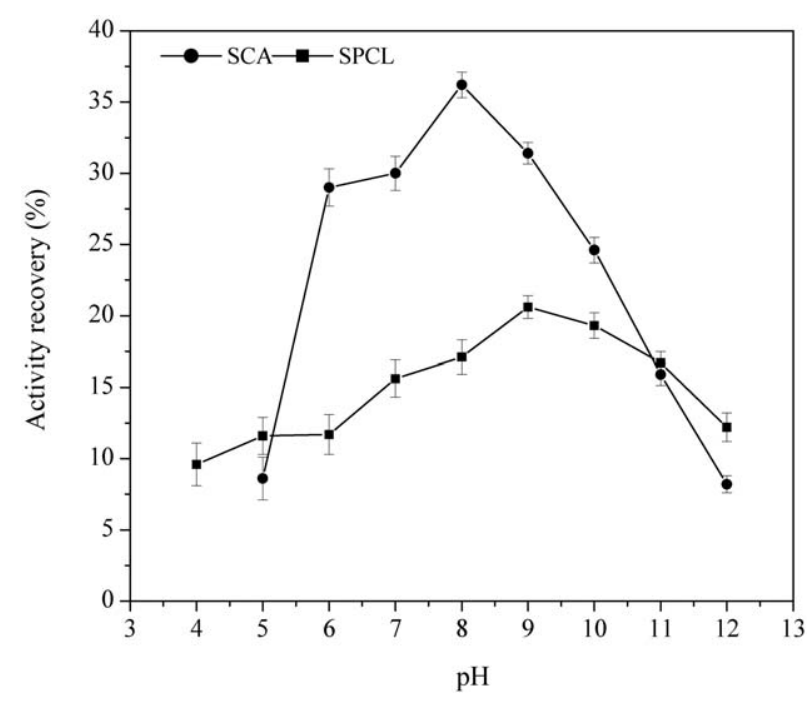

Figure 3 Effect of the $\mathrm{pH}$ of the immobilisation solution on catalase activity recovery (\%) on (- -) SCA and (- -) SPCL. SCA and SPCL were activated with $\mathrm{CNBr}$. 
TAB LE I Half-life (h) of free and immobilised catalases, $\mathrm{pH}$ $7.4 \pm 0.02$ at $37^{\circ} \mathrm{C}$

\begin{tabular}{lll}
\hline Immobilisation methods & \multicolumn{2}{c}{ Half-life $(\mathrm{h})(\mathrm{pH} 7.0)$} \\
\cline { 2 - 3 } & $\mathrm{SCA}$ & $\mathrm{SPCL}$ \\
\hline Epichlorohydrin & 1162 & 870 \\
$\gamma$-ATPS & 730 & 605 \\
$\mathrm{CNBr}$ & 620 & 540 \\
Adsorption & 72 & 24 \\
Free catalase & 480 & \\
\hline
\end{tabular}

\subsection{Stability of the immobilised catalase in buffer solution}

The stability of immobilised enzyme systems is very important for various biomedical and biotechnological applications; increased stability could make the immobilised enzyme more advantageous than its free counterparts [51]. Operational stability of the free and immobilised catalases was determined in terms of halflives after incubation in phosphate buffer $(\mathrm{pH}$ 7.4) at $37^{\circ} \mathrm{C}$ (Table I). The immobilised enzyme showed a considerably longer half-life compared to those found for the free enzyme. The activation process with epichlorohydrin and using PEI as a spacer-arm showed higher half-lives for SCA $(1162 \mathrm{~h})$ and SPCL $(870 \mathrm{~h})$ as compared with other treatments and the free enzyme ( $480 \mathrm{~h})$. This effect can be probably attributed to three factors: (i) the presence of glycerol in the immobilisation medium; (ii) the spacer size; or (iii) the presence of porosity on the support surface. In fact, the spacer molecule seems to give a greater degree of mobility to the coupled biocatalysts, so that its activity can be (under certain circumstances) higher than if it is bound directly to the carrier. It is also well known that porous carriers are often used for the purpose of immobilisation. Their large specific surface areas (area per weight or area per volume) as compared to non-porous carriers typically permit greater loading with biocatalysts, which can result in a much higher specific activity and stability of the enzyme, has been reported by several authors [52-54]. On the other hand, proteins bound on the internal surface are protected from the turbulent and harsh external environment $[55,56]$.

The effect of the various derivatisation procedures used on the SCA and SPCL surfaces were evaluated by SEM. Fig. 5(a) and (b) shows micrographs of the morphology of SCA and SPCL surfaces before the derivatisation and Fig. 5(c, e, g, i) and (d, f, h, j) shows micrographs of the SCA and SPCL surfaces after derivatisation by epichlorohydrin, $\gamma$-ATPS, $\mathrm{CNBr}$, and adsorption methodologies. Clearly, the covalent coupling procedure with epichlorohydrin leads to an altered uneven surface, creating pores on both the SCA and SPCL surfaces (Fig. 5(c) and (d)). The irregular structure could account for the greater enzyme stability observed when using the epichlorohydrin method. The effect of $\mathrm{NaOH}$ and epichlorohydrin chemicals used for surface derivatisation of SCA and SPCL was also investigated. Similar micrographs were obtained when the surfaces of SCA and SPCL were treated with sodium hydroxide and epichlorohydrin solutions separately during $10 \mathrm{~min}$. Fig.

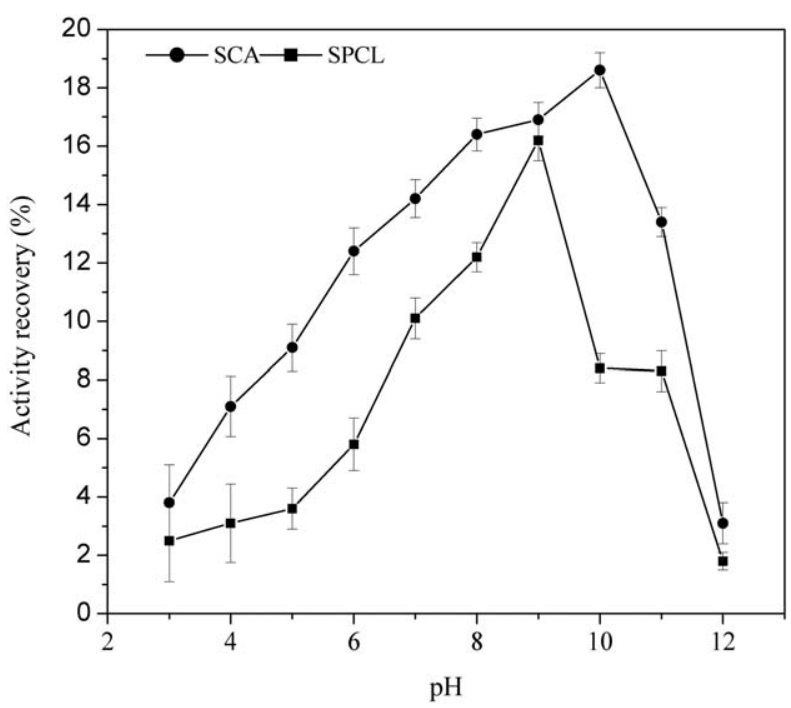

Figure 4 Effect of the $\mathrm{pH}$ of the immobilisation solution on catalase activity recovery (\%) on (- -) SCA and (- - -) SPCL. The catalase was immobilised by adsorption.

$6(a, b)$ and $(c, d)$ showed representative images of how solutions of $\mathrm{NaOH}$ and epichlorohydrin do influence the final surface morphology of the materials. It might be concluded that the attack by the epichlorohydrin solution was more intense on SPCL samples as compared to SCA samples, thus creating surface porosity as can be observed in Fig. 6(b) and (d). In the case of the immobilisation studies, porosity was found to be an advantage in terms of stability of the immobilised catalase. However, the physical properties such as mechanical strength and degradation rates of the materials will be surely affected as it is expected that these samples will have lower mechanical properties and faster degradation rates.

\section{Conclusions}

The purpose of this study was to evaluate several different methodologies for the immobilisation of catalase by physical adsorption and chemical modification on two different starch-based biomaterials, SCA and SPCL. It was possible to observe that the activity recovery $(\%)$ of catalase immobilised into SCA and SPCL was quite dependent of the enzyme $\mathrm{pH}$ solution for all the tested immobilisation procedures. The covalent immobilisation of catalase on SCA and SPCL using epichlorohydrin as activation agent and simultaneously polyethylenimine as a spacer-arm between the enzyme and the support was found to be very efficient in maintaining the stability of catalase. The half-life time of the immobilised enzyme with epichlorohydrin was higher when compared with other treatments and with the free enzyme. In general, the evolution of the half-life is regarded as an indicator for the efficiency of the immobilisation process. The increase in the stability could be attributed to three factors: the presence of glycerol, the dimension of the spacer-arm between the enzyme and the support, and due to the presence of porosity on the SCA and SPCL surfaces as was observed by SEM. In the specific case of SCA, the higher half-life obtained could also be attributed to the presence of 

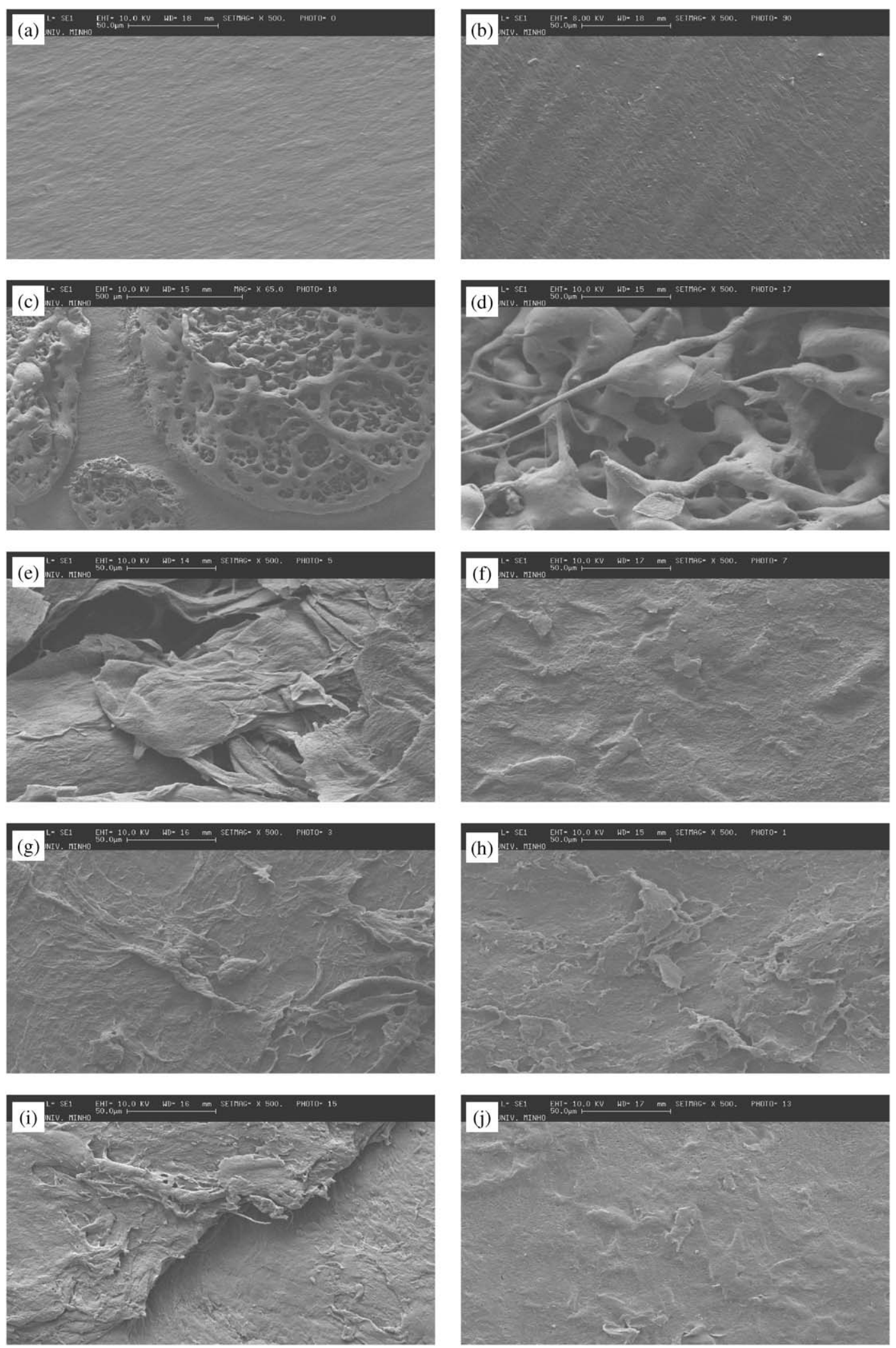

Figure 5 SEM micrographs of (a, b) samples of SCA and SPCL controls, (c, d) sample of SCA and SPCL treated with epichlorohydrin, (e, f) samples of SCA and SPCL without washing and treated with $\gamma$-ATPS, and $(g, h)$ samples of SCA and SPCL treated with CNBr, and (i,j) samples of SCA and SPCL without treatment after immobilisation for adsorption.

higher numbers of hydroxyl groups. The covalent coupling with epichlorohydrin has been shown to be an easy and simple alternative procedure for activating the surface of starch-based biomaterials and can be used for enzyme immobilisation or for incorporation of other useful, active molecules that can improve cellular adhesion on this class of degradable biomaterials. This rationale can be used for tailoring the surface characteristics of starch-based tissue-engineered scaffolds.

\section{Acknowledgment}

Portuguese Foundation for Science and Technology (Post-Doctoral Grant to S. A. Costa, SFRH/BPD/8469/ 

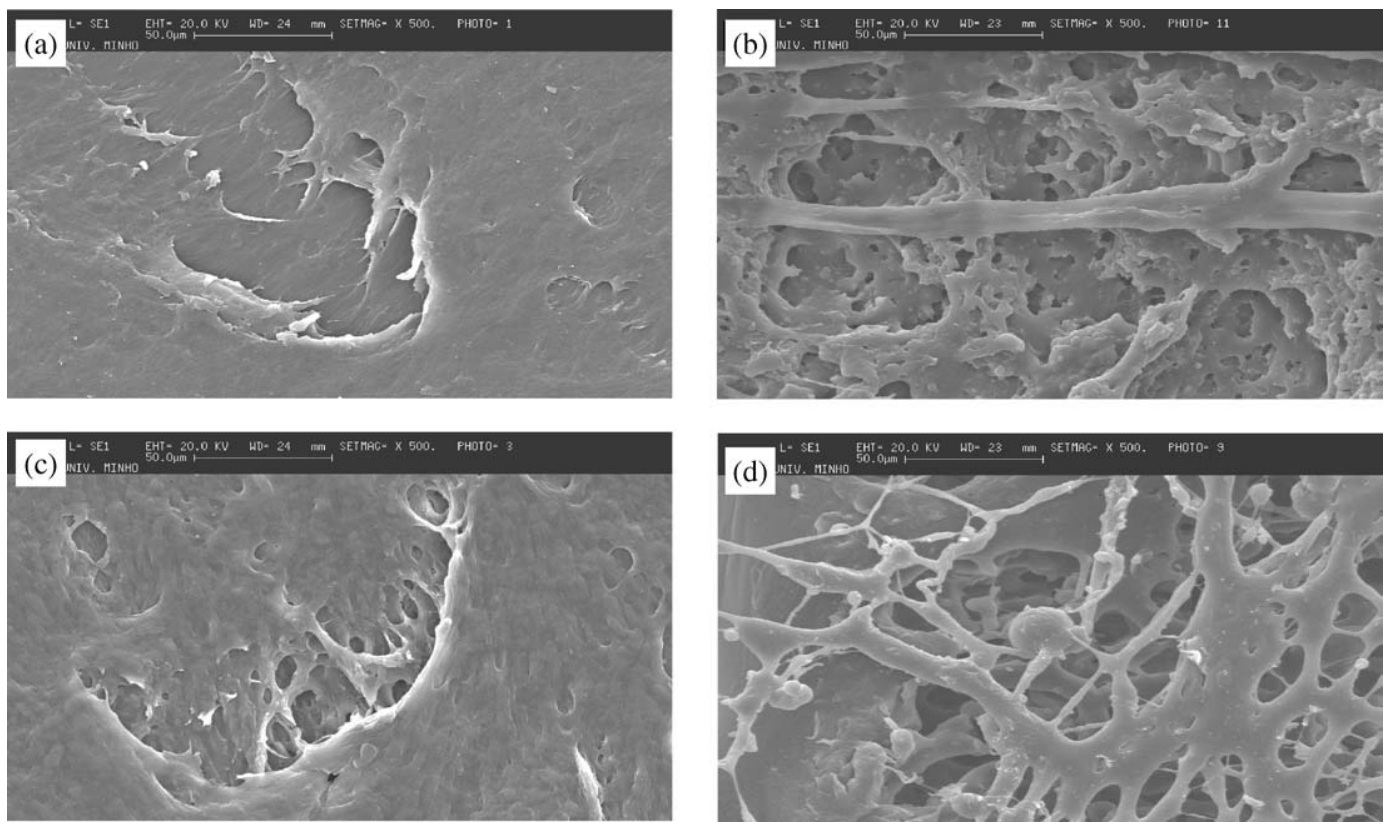

Figure 6 SEM micrographs of $(a, b)$ samples of SCA and SPCL treated with sodium hydroxide, and (c, d) samples of SCA and SPCL treated with epichlorohydrin.

2002 under the POCTI Program). This work was partially supported by FCT through funds from the POCTI and FEDER programs.

\section{References}

1. M. HACKER, J. TESSMAR, M. NEUBAUER, A. BLAIMER, T. BLUNK, A. GÖPFERICH and M. B. SCHULZ, Biomaterials 24 (2003) 4459.

2. M. E. BROZ, D. L. V. HART and N. R. WASHBURN, ibid. 24 (2003) 4181

3. I. CHUNG, D. XIE, A. D. PUCKETT and J. W. MAYs, Eur. Polym. J. 39 (2003) 1817.

4. S. ZHOU, X. DENG and H. YANG, Biomaterials 24 (2003) 3563.

5. G. U. OSTROVIDOVA, A. V. MAKEEV, A. V. BIRYUKOV and S. K. GORDEE V, Mater. Sci. Eng. 23 (2003) 377.

6. M. ZUWEI, G. CHANGYOU, J. JIAN and S. JIACONG, Eur. Polym. J. 38 (2002) 2279.

7. Y. ZHU, C. GAO and J. SHEN, Biomaterials 23 (2002) 4889.

8. Z. BÍLKOVÁ, J. MAZUROVÁ, J. CHURÁCEK, D. HORÁK and J. TUR KovÁ, J. Chromatogr. A. 852 (1999) 141.

9. A. J. SALGADO, M. E. GOMES, A. CHOU, O. P. COUTINHO, R. L. REIS and D. W. HUtMACHER, Mater. Sci. Eng. C 20 (2002) 27

10. A. OlIVEIRA, C. ElVIRA and R. L. ReIS, J. Mater. Sci. Mater. M. 10 (1999) 827.

11. M. KONERACKÁ, P. KOPCANSKÝ, M. ANTALÍK, M. TIMKO, C. N. RAMCHAND, D. LOBO, R. V. MEHTA and R. V. UPHADHYAY, J. Magn. Magn. Mater. 201 (1999) 427.

12. Y. YANG, M. C. PORTÉ, P. MARMEY, A. J. EL HAJ, J. A MÉdÉE and C. B AQUEY, Nucl. Instrum. Meth. B 207 (2003) 165.

13. A. DYBKo, W. WRÓBLEWSKI, J. MACIEJEWSKI, R. ROMANIUK and Z. BRZÓZKA, Sensors Actuat. B Chem. 38 (1997) 207.

14. A. SUbRAMANiAn, S. J. KenNel, P. I. Oden, K. B. JACOBSON, J. WOODWARD and J. DOKTYCZ, Enzyme Microb. Tech. 24 (1999) 26.

15. M. Y. ARICA, V. HASIRC and N. G. ALAEDDINOGLU, Biomaterials 16 (1995) 761.

16. H. J. CHAE, M. J. IN and E. Y. KIM, Appl.Biochem. Biotech. 73 (1998) 195.

17. R. A. QUIRK, W. C. CHAN, M. C. DAVIES, S. J. B. TENDLER and K. M. SHAKESHEFF, Biomaterials 22 (2001) 865.

18. M. T. SOLAS, C. VICENT, L. XAVIER and M. E. LEGAZ, J. Biotechnol. 33 (1994) 63.
19. R. Torres, C. mateo, m. Fuentes, m. palomo, C. ORTIZ, R. F. LAFUENTE and J. M. GUISAN, Biotechnol. Prog. 18 (2002) 1221.

20. S. AKOGÖL, Y. KAÇAR, S. ÖZKARA, H. YAVUZ, A. DENIZLI and M. Y. ARICA, J. Mol. Catal. B Enzym. 15 (2001) 197.

21. P. C. Oliveira, G. M. Alves and H. F. CASTRO, Biochem. Eng. J. 5 (2000) 63.

22. M. S. M. ELDIN, C. G. P. H. SCHROËN, A. E. M. JANSSEN, D. G. MitA and J. TR A MPER, J. Mol. Catal. B Enzym. 10 (2000) 445 .

23. N. Alb Ayrak and S. T. YAng, Biotechnol. Prog. 18 (2002) 240

24. R. GREENWALD, Free Radical Bio. Med. 8 (1990) 201.

25. P. Johnson, Comp. Biochem. Phys. C 133 (2002) 493.

26. E. AKERTEK and L. TARHAN, App. Biochem. Biotech. 50 (1995) 291

27. D. EMERSON, S. F. PETEU and M. R. WORDEN, Biotechnol Tech. 10 (1996) 673.

28. M. ZÁMOCKÝ, G. REGELSBERGER, C. JAKOPITSCH and C OBINGER, FEBS Lett. 492 (2001) 177.

29. A. C. KOTZE, Int. J. Parasitol. 33 (2003) 393

30. L. Gót H, Blood Cell Mol. Dis. 27 (2001) 512.

31. L. GÓTH, Clin. Chim. Acta 311 (2001) 161.

32. S. A. COSTA, T. TZANOV, A. PAAR, M. GUDELJ, G. M GÜBITZ and A. C. PAUlo, Enzyme Microb. Tech. 28 (2001) 815.

33. S. A. ÇETINUS and H. H. ÖZTOP, ibid. 32 (2003) 889.

34. Z. YANG, M. DOMOCH, R. AUGER, F. X. YANG and A. J. RUSSELL, ibid. 18 (1996) 82.

35. K. Z. MAROLIA and S. F. D'SOUZA, J. Biochem. Bioph. Meth. 39 (1999) 115.

36. M. PETRO, F. SVEC and M. J. FRÉCHET, Biotechnol. Bioeng. 49 (1996) 355.

37. M. E. GOMES, J. S. Godinho, D. TCHALAmov, A. M. CUNHA and R. L. REIS, Mater. Sci. Eng. C 20 (2002) 19.

38. A. J. SAlgADo, M. E. Gomes, A. ChOU, O. P. COUTINHo, R. L. REIS and D. W. HUTMACHER, ibid. 20 (2002) 27.

39. M. E. GOMES, A. S. RIBEIRO, P. B. MALAFAYA, R. L. REIS and A. M. CUNHA, Biomaterials 22 (2001) 883.

40. A. L. Oliveira, P. B. MALAFAyA and R. L. Reis, ibid. 24 (2003) 2575.

41. C. M. Alves, R. L. REIS and J. A. HUN T, J. Mater. Sci. Mater. M. 14 (2003) 157.

42. H. E. AEBI, in "Methods of enzymatic analysis", edited H. U. Bergmeyer (Verlag Chemie, Weinheim, 1983) p. 273.

43. S. F. SOUZA and J. S. MELo, Process Biochem. 36 (2001) 677 
44. N. A. DUNG, N. D. HUYEN, N. D. HANG and T. T. CANH, Radiat. Phys. Chem. 46 (1995) 1037.

45. S. A. Costa, T. TZAnov, A. F. CARneiro, A. PAar, G. M. GÜBITZ and A. C. PAUlo, Enzyme Microb. Tech. 30 (2002) 387.

46. M. MATSUMOTO, K. KIDA and K. KONDO, J. Chem. Techmol. Biotechnol. 70 (1997) 188.

47. J. M. S. ROCHA, M. H. GIL and F. A. P. GARCIA, J. Biotechnol. 66 (1998) 61.

48. G. R. CAS TRO, Enzyme Microb. Technol. 27 (2000) 143.

49. R. BAHULEKAR, N. R. AYYANGAR and S. PONRANTHNAM, ibid. 13 (1991) 858.

50. L. A. JURAdo and H. W. JARRETt, J. Chromatogr. A 984 (2003) 9.

51. H. ZHAO, L. A. B Ailey and G. A. GRABOWSKi, Blood Cells Mol. Dis. 30 (2003) 90.
52. C. M. F. SOARES, H. F. D. CASTRO, M. H. A. SANTANA and G. M. ZANin, App. Biochem. Biotech. 91 (2001) 1.

53. G. F. BICKERSTAFF, in "Enzyme in Industry and Medicine", edited by Edward Arnold (Baltimore, 1987).

54. H. E. SWAISGOOD, in " Applications to Bioprocessing of Food Enzymology, in Food Enzymology”, edited by P. F. Fox (Elsevier Applied Science, New York, 1991).

55. W. HARTMEIR, in "Immobilised Biocatalysts" (SpringerVerlag, Berlin, 1986) p. 206.

56. B. SHULZ, A. RIEDEL and P. U. ABEL, J. Mol. Catal. B-Enzym. 7 (1999) 85.

Received 4 October

and accepted 10 October 2003 